\title{
Production and Application of Moringa-Aluminates for Water Treatment as a Facile Biochemical Coagulant
}

\author{
Paul SH, Usman AA, Adeniyi OD and Olutoye MA* \\ Department of Chemical Engineering, Federal University of Technology Minna, Nigeria
}

Submission: February 20, 2017; Published: April 28, 2017

"Corresponding author: Olutoye MA, Department of Chemical Engineering, Federal University of Technology Minna, Nigeria, Email: m.olutoye@futminna.edu.ng

\begin{abstract}
A research into the production and application of moringa-aluminate for water treatments as a facile biochemical coagulant was carried out. In this research work, coagulating materials from Moringa oleifera and Alum, (moringa-aluminate), for purifying water were developed and used to treat different samples of raw water from Gurara Dam in Gurara, Lower Usman Dam in Abuja, Chanchaga Dam in Minna and Bosso Dam in Minna. The quality of the treated water was subsequently determined. Parameters such as pH, turbidity, Dissolved Oxygen, Colour, Conductivity, TDS and temperature were determined from the treated water samples. The results of the analysis for the treated water show that $\mathrm{pH}$ and turbidity, which are important parameters were averagely reduced by $94 \%$ with moringa-aluminate, $91 \%$ with Moringa oleifera seed powder and 95\% with Alum. The results show that Alum and moringa-gave more efficient treatment but Moringa oleifera also produce water of acceptable quality since in both cases the treated water met WHO portable water standard. However, Moringa oleifera has great advantages which made it a better coagulant than Aluminium Sulphate but Moringa-aluminate has even greater advantages when comparing to the two coagulants. Both moringa-aluminate and Moringa oleifera do not affect the $\mathrm{pH}$ of the treated water and their efficiencies are independent of raw water pH. Moringa oleifera is non toxic coagulant but in efficacy of sludge removals, it is less than the two other coagulants. Their application in water treatment give rise to relatively low volume of sludge which is biodegradable and hence an environmentally benign technology. Also, the use of Moringa oleifera gives rise to low cost water treatment and it can be produced locally. Thus, indigenous plant species possessing both coagulating and antimicrobial properties was discovered and used for the development of a modern, efficient and optimum coagulant for all purpose water treatment. Moringa oleifera, was found to provide a good economical and sustainable alternative raw material and can be used simultaneously with Alum to find solution to the use of Aluminium Sulphate (which is conventional chemical coagulant) which excess residue on treated water cause deadly diseases.
\end{abstract}

Keywords: Raw Water; Moringa-aluminate; Moringa oleifera; Facile \& coagulants

\section{Introduction}

Water is an essential, indispensable and irreplaceable requirement for human survival [1]. It covers about $70 \%$ of the Earth's surface and makes up about $70 \%$ of human body mass as well. It is however one of the most essential ingredients for living and life because of its multi-applications in human affairs (Donaldson, 2013). There are many sources of water such as; rain water, surface water (which include rivers, lakes, streams, reservoirs and seas) and underground water like; springs, wells, galleries, infiltrations and so on). It has been reported that the total amount of water in the world is about 1400 million cubic $\mathrm{km}\left(10^{18}\right.$ tonnes) and remains constant (with reference to water cycle 207) Apparently, more than $97 \%$ of this total volume is sea water of the rest $22 \%$ is ground water and $77 \%$ is ice locked away in the glaciers and the polar ice cap [2]. This obviously leaves less than $1 \%$ of the supply of fresh water, which takes in the water hydrological cycle but half of this is found in rivers, lakes, and swamps (Donaldson, 2013). Most of the fresh or accessible water bodies are polluted that is to say; are unfit for domestic activities, drinking and even some industrial functions [3]. Hence the needs for well treated, affordable, accessible, available and quality water supply have become imperative [4]. The search for raw materials with characteristics and properties that favours these objectives has been the quest of every objectives and purpose driven academics [5]. The present climate change that have unbalanced the circle of life, have left man with no option than to judiciously utilize his resources for healthy body chemistry and environment at large [6]. The development of coagulants to meet the demand for quality water, with deliberate long time health advantages is the focus of modern researchers [7].

Moringa-aluminates is a biochemical compound consisting of Aluminium Sulphates and Moringa Oleifera [8]. It is a newly 
developed coagulant that has imbedded in it the characters of biological coagulations/flocculation and the inorganic characters of chemical coagulations/flocculation as well. It is a well balanced, simple and effective organochemical coagulants; the needed coagulant of the $21^{\text {st }}$ century and beyond. The properties of aluminium sulphate $\left(\mathrm{Al}_{2}\left(\mathrm{SO}_{4}\right)_{3}\right)$; an inorganic chemical substance and those of Moringa oleifera a special organic compound that has multiples applications in the industry, domestic, medicinal/pharmaceutical and food market. This chemical compound is believed to have greater water treatment properties when compared to any other coagulant be it biocoagulant or inorganic chemical coagulant. This is because where the bioactive constituents of Moringa oleifera are deficient, the chemo-active constituents of alum will compliment and vice versa. In other words, using moringa-aluminate as a biochemical coagulant handles every disadvantages both sides given a balanced, efficient, effective and excellent coagulant suitable for optimum turbidity handling properties for the treatment of both effluent water and other related polluted water for domestics, industrial and pharmaceuticals that required water for their functionalities and development [9].

Moringa oleifera has a wide distribution because of its excellent and diversified application in almost every facet of human life. It is said to be one of the best and most naturalized known monogeneric (Moringaceae) plant family in the world [9]. The plant has noticeable medicinal qualities, foods characteristics (proteins content vitamins and sugar etc) and excellent water treatments efficacy including anti- bacterial functions (Farooq et al, 2006). The water treatment efficacy of Moringa oleifera prompted this research (Eman et al, 2009).

Alum has been the most commonly used chemical coagulant for both industrial and urban water treatment in most counties of the world especially developing countries like Nigeria. The used of alum as a coagulant, does not come without its own challenges and setbacks as recent studies haves shown that some serious diseases are associated with the used of Aluminium salts. Such drawbacks include Alzheimer's diseases and strong carcinogenic effects which are associated with high aluminium residuals in treated water, excess sludge formation during water production and its dependent on water $\mathrm{pH}$ (Schwarz D 2000). In addition to the above setbacks the cost of importation into developing countries cannot be rules out therefore it is inappropriate to used alum in water treatment in high dosage hence Moringa-aluminates provides an alternative route to overcome the challenges [10]. Recent researchers have pointed out that there are plants origin extracts that has water treatment efficacies possessing both coagulating and anti-bacterial properties and when used in water treatment, it's become safe for human consumption (Katayon et al. 2005). The seeds from Moringa oleifera fruits are such extracts that has water treatment to capability exhibiting high coagulating and anti-bacterial proficiencies in addition to medicinal/health advantages which makes it an efficient substitute to alum and other metal salts used for water treatment. Less cost of water production, less sludge formation and availability of the coagulant However some of its setbacks are; excess nutrients, less effectiveness in bacterial destruction and chemical oxygen demand (COD) due to its organic nature as a biocoagulant [11]. Furthermore, research have shown that among all the known plants with water treating efficacies that have been tested, the seeds from Moringa has been adjudged to be one of the most effective and efficient primary coagulant for water treatment when compared to the conventional chemical for treating water Aluminium Sulphate (Al2 (SO4)3 ) (Jacob et al. 2010).

Moringa-aluminates however, is the best substitute for both Alum and Moringa Oleifera because; it contained all the advantages of Moringa Oleifera and those of Aluminium Sulphate and compliment each other's weaknesses and deficiencies. For instance the high concentration of aluminiums in the treated water which has negative health effects are highly reduced in this formulation by fifty percent when Alum reacts with those negatively charged suspended particles, the remaining nutrient from Moringa constituent are removed by this alum during the process as either sludge or through precipitation (Yogabi et al, 2009). The less effectiveness of Moringa compared to Alum in terms of anti-bacterial functions and turbidity reduction, are settled since Alum that is effective in this regard is presence to do the job. This facile biocoagulant chemical coagulant is in fact an optimum coagulant for balancing in the water production industry [12-14]. With greater health, economics and industrial opportunities for the developing and as well-developed wall (Katayon et al. 2005 \& Jacob, 2010). In this research work, the potency of moringa-aluminate and it application will be compared to those of ALUM and Moringa oleifera. Water Parameters like turbidity, $\mathrm{pH}$ colour, conductivity, total dissolved solids (TDS), Dissolved oxygen and temperature of raw water as well as treated water will be investigated (Donaldson 2013). The investigation is aimed at finding out the best coagulant, more effective and efficient for raw water treatment and has both present and long term positive effects on consumers' as well the environment. Also, acceptable to world Health organization (WHO) and standard organization of Nigeria. This will reduce water related diseases that have ravaged mankind and other aquatic organisms.

\section{Materials and Methods}

Samples for this investigation work were obtained from different Dams vix: Bosso dam in minna with the carrying capacity of 680,000 cubic meters Chanchaga Dam in minna with capacity of 26,500 million cubic meters, Gurara Dam in Niger state with capacity of 880 million cubic meters, Usuma Dam in Abuja with capacity of 100 milliom cubic meters. The apparatus and machines were gotten from Niger state water works Nigeria $[15,16]$. 


\section{Materials}

The materials used for this research includes Moringa oleifera seeds, Aluminium sulfate, distilled water and raw water. Equipments like; mortar \&pestle, weighing Balance, grinder/ crusher, sieving Mesh, pH meter, Turbidity meter, colorimeter, conductivity meter, Electronic stirring machine Dissolved oxygen meter and thermometer were all obtained from FUTMinna and Water Quality laboratory River Basin Minna Niger State Nigeria and Niger state water Board.

\section{Preparation of coagulants and pre-treatment}

The alum \& Moringa oleifera were crushed using a mortar and pestle. $500 \mathrm{~g}$ of dehusked Moringa seed and 500g of Alum were crushed. In order to increase the surface area of the Alum and Moringa, hence the crushed powders were further crushed into finer particles. This was done to; enable the bioactive part of the two coagulants and raw materials for Moringa-aluminate production. Grounded samples were screened to obtain the desirable sizes of the samples of $0.2 \mathrm{~mm}$. $50 \mathrm{~g}$ of Moringa oleifera powder and 50g of Aluminium Sulphate were measured and blended together. The thoroughly blended powder was then packed in a polyethylene bag.

\section{Preparation of moringa coagulant Solution and the method of treatment}

The $100 \mathrm{~g}$ of Moringa powder was mixed with $40 \mathrm{~cm}^{3}$ of clean water distilled water precisely into a liquid. The milky solution was added to 2 litres of the turbid water from Lower Usuma Dam and stirred fast for half a minute then slowly and regularly stirred for about five minutes. After stirring, the treated water was covered and left to settle for one hour. Care was taken not to shake the system because it may cause clarification to take much longer or fail to reach completion. The same procedures for treatment were carried out on the remaining samples of raw water from Bosso Dam, Gurara Dam and Chanchaga Dam from Niger state.

\section{Preparation of alum coagulant solution and the method of treatment}

The powdered Alum (100g) was mixed with $40 \mathrm{~cm} 3$ of clean water to form a solution of the same concentration as Moringa oleifera solution. The solution was added to raw turbid water from Gurara Dam 2 litres and stirred fast for 30 seconds. This was followed by a gentle stirring for 5 minutes, after which the samples were allowed to stand and settle for 60 minutes. The same procedures were carried out on the remaining raw water samples from Chanchaga Dam, Bosso Dam, and Usuma Dam.

\section{Preparation of Moringa-aluminate}

The powdered Moringa-aluminate $(100 \mathrm{~g})$ was mixed with $40 \mathrm{~cm}^{3}$ of clean water to form a solution of the same concentration as Moringa oleifera solution and Alum. The solution was added to raw turbid water from Chanchaga Dam 2 litres and stirred fast for 30 seconds. This was followed by a gentle stirring for
5 minutes, after which the samples were allowed to stand and settle for 60 minutes. The same procedures were carried out on the remaining raw water samples from Usuma Dam, Bosso Dam, and Gurara Dam.

\section{Analysis of water}

The following analyses were carried out on the water samples before and after treatment with Moringa oleifera and Aluminium Sulphate. The analysis followed world health organization standard procedure for analysis of treated water.

\section{Results and Discussions}

\section{Results}

At the course of this work, the following results were obtained. The results are from analysis of four samples of water collected from different water works/boards. The analysis of both the raw water and the treated water, are presented in Tables 1-4 as shown below:

\section{Discussion}

From the results of analyses conducted and shown in the Tables, the $\mathrm{pH}$ values of the four samples of raw water were 7.56, 7.46, 7.55 and 7.60 for Gurara Dam, Usuma Dam, Chanchaga and Bosso Dam respectively the result of $\mathrm{pH}$ becomes 7.36, 7.26, 7.37 and 7.48 respectively when treated with moringa-aluminate. This results when compared; show that $\mathrm{pH}$ is only slightly affected by the present of the coagulant which demonstrates great advantage of the coagulant functioning slightly independent of $\mathrm{pH}$ of the raw water. The independency trend is equally demonstrated by the $\mathrm{pH}$ result of samples treated with only Moringa oleifera seeds as listed below: 7.42, 7.50, 7.57 and 7.36 for the four samples respectively. However, the $\mathrm{pH}$ of treated samples are within who standard range of 6.5-8.5. From the result $(6 . \backslash 52,6.23,6.98$ and 6.44). Alum as a coagulant is affected by the $\mathrm{pH}$ of raw water within which it used and this is one of its setbacks. The result as discussed above, showed that Moringa oleifera can be used to treat raw water independent of the $\mathrm{pH}$ range of the water Moringa-aluminate followed the same trend of independency but with slight sensitivity to $\mathrm{pH}$ because of the presence of Alum in it this means that treatment with Moringa Oleifera does not modify the raw water $\mathrm{pH}$ even after treatment as well as Moringa-aluminate. On the other hand, Alum as an inorganic coagulant has a $\mathrm{pH}$ range within which it functions (5.8-8.5) anything outside this, there is a need for pretreatment with acid or base respectively however the four samples of water used, are within this stipulated range. Since Alum is acidic, it affects (modifies) the $\mathrm{pH}$ of water when used as a coagulant that is, it increased the acidity of the system given $\mathrm{pH}$ values less than that of the raw water.

The turbidity values obtained when the four raw water samples were analyzed and those that were treated with Moringaaluminate, Moringa oleifera seed powder and alum analyzed, were: $48.20 \mathrm{NTU}, 49.50 \mathrm{NTU}, 50.60 \mathrm{NTU}$ and $60.10 \mathrm{NTU}$ for raw 
samples of water collected from Gurara Dam, Lower Usuma Dam, Chanchaga Dam and Bosso Dam respectively. For Moringaaluminate, the turbidity values were 2.60NTU 2.28NTU, 2.82NTU and $2.24 \mathrm{NTU}$ in that order. For Moringa oleifera, the turbidity values obtained were 5.10 NTU, 4.33 NTU, 3.62 NTU and 4.24 NTU for sample of water from Gurara Dam, Lower Usuma Dam, Chanchaga Dam and Bosso Dam respectively. For Aluminium Sulphate, the results obtained were 2.31 NTU, 2.62 NTU, 2.22 NTU and 2.36 NTU From the above results it could be seen that the higher the turbidity of the raw water, the more effective the effect of both coagulants. This is so because, the raw water with the highest turbidity has more negatively charged particulates that makes raw water more turbid (silt, clay, bacteria and so on). This implies that it has greater attractive force compared to those with lower turbidity; and as such, attracts faster the overall positive charges of the coagulants by improving coagulation and building stronger and more settleableflocs. This in turn gives rise to clearer water. Also, from the results, it can be seen that Moringa oleifera is less effective in turbidity removal compared to moringa-aluminate and Aluminium Sulphate. However, water turbidity when treated with the three coagulants were within the acceptable limits for drinking water production (i.e. 5 NTU) as stipulated by W.H.O. Aluminiumsulphate has greatest turbidity removal efficiency Moringa-aluminate is next with almost the same efficacy and Moringa oleifera is the least because, from literature (Science world journal, 2009), the concentration of Aluminium, $\mathrm{Al}$ (which is an active coagulating agent) is higher in Alum, high in moringa-aluminate than in Moringa oleifera. In other word, Alum has greater affinity for particles of turbid water followed by Moringa-aluminate than Moringa oleifera . It is worthy of note that Moringa oleifera averagely reduces the turbidity by $91 \%$ while moringa-aluminate reduces it by $94 \%$ and Alum by $95 \%$.

The Colour of the four raw water samples measured in TCU (total colour unit) and the results recorded as: $296 \mathrm{TCU}, 358 \mathrm{TCU}$, 379 TCU and 386 TCU. When the water samples were treated with Moringa-aluminate, the following colours were obtained: 16 TCU, 15 TCU, 17 TCU and 19 TCU. The results of Moringa oleifera seed powder were found to be $23 \mathrm{TCU}, 28 \mathrm{TCU}, 24 \mathrm{TCU}$ and 22 TCU. The result for Alum is: 15 TCU, 16 TCU 17TCU and 16 TCU for samples of water from Gurara Dam, Lower Usuma
Dam, Chanchaga Dam and Bosso Dam respectively. Colour is the physical appearance of a substance or a liquid. Colour measured as a "true colour" (Turbidity removed) is classified by comparison of the sample with a known concentration of colour is usually due to the presence of coloured organic matter (primarily humic and fulvic acids) associated with the humus fraction of soil. It is also influenced by the presence of iron and other metals, either as natural impurities or corrosion products. It may also result from the contamination of the water source with industrial effluents according to (WHO, 2006). Though the results above are greater than the value of standard colour i.e. $15 \mathrm{TCU}$, this is because the threshold turbidity required to be removed is not attained (i.e. 0.1 NTU as a goal from literature) (WHO, 2004). This was not achieved because; the clarified water was not passed through appropriate filters for further removal of turbidity which is beyond the scope of this work. Although, Alum and Moringa-aluminate have the most preferred result when compared to standard of 0.1 TCU even though Moringa oleifera is very effective and efficient as well (Horseradish T 2003). The results of analysis as shown in Tables 1-4 revealed that the conductivity of the water samples treated with both coagulants It shows the conductivity of untreated raw water and those treated with moringa-aluminate, Moringa oleifera seed powder and Alum to be $246 \mu \mathrm{S} / \mathrm{cm}, 228 \mu \mathrm{S} / \mathrm{cm}, 176 \mu \mathrm{S} / \mathrm{cm}$ and $198 \mu \mathrm{S} / \mathrm{cm}$. for those of moringa-aluminate, $122 \mu \mathrm{S} / \mathrm{cm}, 104 \mu \mathrm{S} /$ $\mathrm{cm}, 126 \mu \mathrm{S} / \mathrm{cm}$ and $124 \mu \mathrm{S} / \mathrm{cm}$ for samples of water from Gurara Dam, Lower Usuma Dam, Chanchaga Dam and Bosso Dam respectivel. that of Moringa oleifera was found to be $119 \mu \mathrm{S} / \mathrm{cm}$, $220 \mu \mathrm{S} / \mathrm{cm}, 167 \mu \mathrm{S} / \mathrm{cm}$ and $144 \mu \mathrm{S} / \mathrm{cm}$, For Alum, it was found to be $106 \mu \mathrm{S} / \mathrm{cm}, 122 \mu \mathrm{S} / \mathrm{cm}, 115 \mu \mathrm{S} / \mathrm{cm}$ and $120 \mu \mathrm{S} / \mathrm{cm}$ for samples of water from Gurara Dam, Lower Usuma Dam, Chanchaga Dam and Bosso Dam respectively. The result shows that treated water in both cases has good conductivity. Thus, from literature, it is seen that potable water registers conductivity from 50-500 $\mu \mathrm{S}$ / $\mathrm{cm}$ (WHO, 2006). Conductivity is the ability of the water to conduct an electrical current, and is an indirect measure of the ion concentration. The more ions present, the more electricity can be conducted by the water. The Effects of physical parameters such as: $\mathrm{pH}$, Turbidity Dissolved Oxygen Colour Conductivity Total dissolved Solid (TDS) and Temperature on the raw and treated water were duely considered and recorded.

Table 1: Results of Raw Water before Treatment.

\begin{tabular}{|c|c|c|c|c|}
\hline Sample A & $\begin{array}{c}\text { Sample A } \\
\text { (Gurara Dam) }\end{array}$ & $\begin{array}{c}\text { Sample B } \\
\text { (Lower Usuma Dam) }\end{array}$ & $\begin{array}{c}\text { Sample C } \\
\text { (Chanchaga Dam) }\end{array}$ & $\begin{array}{c}\text { Sample D } \\
\text { (Bosso Dam) }\end{array}$ \\
\hline $\mathrm{pH}$ & 7.56 & 7.46 & 7.55 & 7.60 \\
\hline Turbidity (NTU) & 48.20 & 49.50 & 50.60 & 2.82 \\
\hline Dissolved Oxygen (mg/L) & 2.94 & 2.86 & 379 & 386 \\
\hline Colour (TCU) & 296 & 358 & 176 & 198 \\
\hline Conductivity $(\mu \mathrm{S} / \mathrm{cm})$ & 246 & 228 & 119.36 & 134.27 \\
\hline TDS $(\mathrm{mg} / \mathrm{L})$ & 162.24 & 150.74 & 26.00 & 27.10 \\
\hline Temperature $\left({ }^{\circ} \mathrm{C}\right)$ & 26.00 & 25.10 & & \\
\hline
\end{tabular}




\section{Current Trends in Biomedical Engineering \& Biosciences}

Table 2: Results of Water Samples after Treating with Moringaaluminate.

\begin{tabular}{|c|c|c|c|c|c|}
\hline \multirow{2}{*}{ Parameters } & $\begin{array}{c}\text { Sample A } \\
\text { (Gurara Dam) }\end{array}$ & $\begin{array}{c}\text { Sample B (Lower } \\
\text { Usuma Dam) }\end{array}$ & $\begin{array}{c}\text { Sample C } \\
\text { (ChanchagaDam) }\end{array}$ & $\begin{array}{c}\text { Sample D } \\
\text { (Bosso Dam) }\end{array}$ & WHO \\
\hline $\mathrm{pH}$ & 7.36 & 7.26 & 7.37 & 2.24 & $5.5-8.5$ \\
\hline Turbidity (NTU) & 2.60 & 2.28 & 2.81 & 0.76 & 5 \\
\hline $\begin{array}{c}\text { Dissolved Oxygen } \\
(\mathrm{mg} / \mathrm{L})\end{array}$ & 0.98 & 0.87 & 0.94 & 19 & 124 \\
\hline Colour $(\mathrm{TCU})$ & 16 & 15 & 126 & 400 \\
\hline Conductivity $(\mu \mathrm{S} / \mathrm{cm})$ & 122 & 104 & 79.99 & 89.18 & $>300$ EXCELLENT \\
\hline TDS $(\mathrm{mg} / \mathrm{L})$ & 78.06 & 78.70 & 26.20 & 27.80 & Ambient \\
\hline Temperature $\left({ }^{\circ} \mathrm{C}\right)$ & 25.50 & 26.10 & 17 & 5 \\
\hline
\end{tabular}

Table 3: Results of Water Samples after Treating with MoringaOleifera seed powder.

\begin{tabular}{|c|c|c|c|c|c|}
\hline Parameters & $\begin{array}{c}\text { Sample A } \\
\text { (Gurara Dam) }\end{array}$ & $\begin{array}{c}\text { Sample B } \\
\text { (Lower Usuma } \\
\text { Dam) }\end{array}$ & $\begin{array}{c}\text { Sample C } \\
\text { (Chanchaga } \\
\text { Dam) }\end{array}$ & $\begin{array}{c}\text { Sample D } \\
\text { (Bosso Dam) }\end{array}$ & $\begin{array}{c}\text { WHO } \\
\text { standard }\end{array}$ \\
\hline $\mathrm{pH}$ & 7.42 & 7.50 & 7.57 & 7.36 & $6.5-8.5$ \\
\hline Turbidity (NTU) & 5.10 & 4.33 & 3.62 & 4.24 & 5 \\
\hline $\begin{array}{c}\text { Dissolved Oxygen } \\
(\mathrm{mg} / \mathrm{L})\end{array}$ & 0.94 & 0.88 & 0.96 & 0.74 & 5 \\
\hline Colour (TCU) & 23 & 28 & 24 & 22 & 15 \\
\hline $\begin{array}{c}\text { Conductivity }(\mu \mathrm{S} / \\
\mathrm{cm})\end{array}$ & 119 & 220 & 167 & 144 & 400 \\
\hline TDS (mg/L) & 79.16 & 140.72 & 131.98 & 89.74 & >300 EXCELLENT \\
\hline Temperature $\left({ }^{\circ} \mathrm{C}\right)$ & 25.50 & 26.00 & 27.40 & 26.80 & Ambient \\
\hline
\end{tabular}

Table 4: Results of Water Samples after Treating with Alum.

\begin{tabular}{|c|c|c|c|c|c|}
\hline Parameters & $\begin{array}{c}\text { Sample A } \\
\text { (Gurara Dam) }\end{array}$ & $\begin{array}{c}\text { Sample B } \\
\text { (Lower Usuma Dam) }\end{array}$ & $\begin{array}{c}\text { Sample C } \\
\text { (Chanchaga Dam) }\end{array}$ & $\begin{array}{c}\text { Sample D } \\
\text { (Bosso Dam) }\end{array}$ & $\begin{array}{c}\text { WHO } \\
\text { standard }\end{array}$ \\
\hline $\mathrm{pH}$ & 6.52 & 6.23 & 5.98 & 6.44 & $6.5-8.5$ \\
\hline Turbidity (NTU) & 2.31 & 2.62 & 2.22 & 0.90 & 5 \\
\hline $\begin{array}{c}\text { Dissolved Oxygen } \\
(\mathrm{mg} / \mathrm{L})\end{array}$ & 0.76 & 0.81 & 0.75 & 18 & 5 \\
\hline Colour $(\mathrm{TCU})$ & 15 & 16 & 17 & 120 & 15 \\
\hline Conductivity $(\mu \mathrm{S} / \mathrm{cm})$ & 106 & 122 & 77.05 & 80.4 & >300 EXCELLENT \\
\hline TDS $(\mathrm{mg} / \mathrm{L})$ & 73.03 & 85.76 & 26.80 & 27.50 & Ambient \\
\hline Temperature $\left({ }^{\circ} \mathrm{C}\right)$ & 26.10 & 27.40 & & 115 & \\
\hline
\end{tabular}

\section{Conclusion}

The results obtained revealed moringa-aluminate to be a facile, effective, efficient and reliable alternative to Alum. The presence of Moringa bioactive component in the coagulant will not only help in turbidity removal but also inpathogenic elimination. The action of this coagulant does not only give rise to a superior coagulant but also an optimum coagulant with its content at best. The production of Moringa-aluminate, have solved the problems of excess aluminium residue in treated water, tendency of cancer due to this deposits and the relatively low turbidity removals of Moringa and micro organism are solved. Although Moringa oleifera is less effective in turbidity removal compared to moringa-aluminate and Aluminium Sulphate; yet, the turbidity of the treated water when Moringa oleifera is used was within acceptable limits for potable drinking water production (i.e. 5 NTU). Moringaaluminate is an intermediary coagulant between aluminium sulphate and Moringa oleifera seed powder the weaknesses of each sources raw materials are complimented by the strength of the other. Because of it unique properties, water of any $\mathrm{pH}$ can be treated using this coagulant (Folkard, 2009). Based on the results obtained, it can be concluded that moringa-aluminate and Moringa oleifera provide very good, cheap and sustainable alternatives solutions to the use of Aluminium Sulphate. In this research work, moringa-aluminate and Moringa oleifera have proven to be active, medically suitable, environmentally safe and inexpensive coagulants for the treatment of raw turbid water for human consumption either at household, community 
levels or even at industrial level. In this work, a discovery of an indigenous, economical plant species and production of facile coagulant was made.

\section{References}

1. Fuglie, Lowell J (1999) The miracle tree: MoringaOleifera. Natural nutrition for the Tropics. Training Manual.

2. Bucheli M (2009) UV disinfection of drinking water in Switzerland: situation, regulations and practice. $5^{\text {th }}$ IUVA World Congress, European Regulatory Workshop, Amsterdam.

3. Bennett RN, Mellon FA, Foidl N (2003) Profiling Glucosinolates and phenolics in vegetative and reproductive Tissues of the multi-purpose Trees Moringa Oleifera (Horseradish Tree, and Moringa Stenopetala. J Agric Food Chem 51(12): 3546-3553.

4. Lockett, Cassius, Calvert, Christopher, Grivetti, et al. (2000) Energy and micronutrient composition of dietary and medicinal wild plants consumed during drought. Study of Fulani, Northeastern Nigeria. Int J Food Sci Nutr 51(3): 195-208.

5. Jpelaar GF, van der Meer B, Medema GJ, Kruithof JC (2003) Byproduct formation during UV disinfection of a pre-treated surface water. Proceedings of the $2^{\text {nd }}$ International Congress on Ultraviolet Technologies, Austria, p. 9-11.

6. OseiAbabio (2004) New School Chemistry for Senior Secondary School. Africana first publisher limited ( $3^{\text {rd }}$ edn). Pp. 429.

7. Katayon S, Megat Mohd Noor MJ, Asma M, Thamer AM, LiewAbdullah $A G$, et al. (2005) Effects of storage duration and temperature of Moringa Oleifera stock solution on its performance in coagulation. Bioresour Technol 97(13): 1455-1460.
8. Abuye C, Omwega AM, Imungi JK (1999) Familial tendency and dietary association of goiter in Gamo-Gofa, Ethiopia. East Afr Med J 76(8): 447 451.

9. Kashinkunti R, Linden KG, Shin G, Metz DH, Sobsey MD, et al. (2003) Achieving multi-barrier inactivation inCincinnati: UV, byproduct and biostability. Journal of the American Water Works Association 96(6): 114-127.

10. Joyce MF (2010) Ultra-violet disinfection as part of a multi-barrier solution for control of Cryptosporidium in drinking water - with case study reference to implemented disinfection solutions in Galway City. CIWEM ROI.

11. WHO (2009) Risk Assessment of Cryptosporidium in Drinking Water. World health Organization.

12. Folkard G, Shaw F, Sutherland J (1999) Technical brief 60(1): 7.

13. Olsen A (1987) Low technology water purification by Bentonite clay and Moringa Oleifera seeds flocculation as performed in Sudanese village: effects of Schistosoma Mansoni Cericariae. Water Res 21: 8192.

14. Peter Gebbie (2006) Earth Tech Engineering $31^{\text {st }}$ Annual Qld Water Industry Workshop. Operations Skills University Central Queensland.

15. Schwarz Dishna (2000) Water clarification using Moringa Oleifera. Technical information Wbe, Gate Information Service, Germany.

16. Science world journal 2009. 4(4).

17.WHO (2004) Guidelines for drinking water quality. Vol 1 Recommendations ( $3^{\text {rd }}$ edn.). Geneva, Switzerland.

18. WHO (2006) Guideline for drinking-water quality (electronic resources): incorporating first addendum ( $3^{\text {rd }}$ edition $)$.

\section{Your next submission with Juniper Publishers} will reach you the below assets

- Quality Editorial service

- Swift Peer Review

- Reprints availability

- E-prints Service

- Manuscript Podcast for convenient understanding

- Global attainment for your research

- Manuscript accessibility in different formats ( Pdf, E-pub, Full Text, Audio)

- Unceasing customer service

Track the below URL for one-step submission https://juniperpublishers.com/online-submission.php 